\title{
GIS-Based Model to Assess Erosion Sensitivity in Northern Morocco. Laou Watershed Case Study
}

\author{
Ahmed Raissouni $^{{ }^{*},}$, Lamiae Khali Issa ${ }^{1}$, Abdelkrim El Arrim ${ }^{1}$, M. Maâtouk ${ }^{1}$, Roberto Passalacqua ${ }^{2}$ \\ ${ }^{1}$ Laboratory of Environment, Oceanology and Natural Resources (LEORN), Department of Earth Sciences, \\ Faculty of Sciences and Techniques, Abdelmalek Essaâdi University, Tangier, Morocco \\ ${ }^{2}$ Department of Civil, Environmental \& Building Engineering (DICAT), University of Genoa, Genoa, Italy \\ Email: *ah_raissouni@hotmail.com
}

Received February 13, 2012; revised March 16, 2012; accepted April 15, 2012

\begin{abstract}
This application on the Laou watershed represents the first part of study results that concerns the development of a model for mapping soil susceptibility at a regional scale in northern Morocco using spatial databases and Geographic Information Systems (GIS). The model uses qualitative decision rules and hierarchical organization of data represented by different thematic maps. Those laters are derived from input erosion parameters which are coded according to their sensitivity to water erosion. Superposing effect of several layers: geology, geomorphology, land use and topography, allows we the obtaining of a qualitative map showing the potential sensitivity to erosion per unit area. The obtained map shows that severe erosion affects the Southern and North-western sectors of the basin, even if they present the least erodible lands of all the basin and have, as well, a relatively dense plant cover. It may be concluded that both high gradient and damaged terrain state represent the main factors of water erosion in the Laou watershed.
\end{abstract}

Keywords: Soil Erosion; Laou Watershed; Environment; GIS

\section{Introduction}

\subsection{Definitions and Basic Concepts}

Soil, usually referred to as "land", is generally defined as the top layer of the earth's crust formed by mineral particles, organic matter, water, air and living organisms. It is essentially a non-renewable resource with potentially rapid degradation rates and extremely slow formation and regeneration processes.

Soil erosion is a natural geological phenomenon and a serious geo-environmental problem worldwide [1]. It is defined as the loosening, dissolving and removal of rock materials from all parts of the earth's surface triggered by a complex interaction process of many factors: natural (climate, topography, soil, vegetation) and antropogenic (tillage systems, soil conservation measures, overgrazing and deforestation) $[2,3]$.

The results of soil erosion are the loss of soil functions and ultimately the loss of soil itself [4]. Consequent damages could be on-site such as the loss of soil and nutrient and could also be out-site such as pollution and siltation of water resources and reservoir sedimentation. However, those latter are usually more costly and severe than the on-site effects [5-7].

\footnotetext{
${ }^{*}$ Corresponding author.
}

Therefore, the identification of erosion factors and vulnerable areas to soil erosion could be very helpful to evaluate the expansion and the degree of the risks and, ultimately, to develop conservation measures and soil/ water management plans.

\subsection{Overview and Objectives}

During the twentieth century, the erosion has increased dramatically worldwide. About $85 \%$ of land degradation in the world is associated to the soil erosion, most of which occurred during the last five decades, causing 17\% reduction in crop productivity [8,9]. In an overview of global erosion and sedimentation, reference [10] stated that more than $50 \%$ of the world's pastureland and about $80 \%$ of agricultural land suffer from significant erosion [7].

The Mediterranean region is historically the most affected by erosion since it is subject to long dry periods followed by heavy bursts of erosive rain, falling on steep slopes with fragile soils. In parts of the Mediterranean region, the erosion has reached a stage of irreversibility [11,12].

In Morocco, soils are eroded to rates that exceed extremely international standards as well as the rate of pedogenesis under the Mediterranean climate. Some agri- 
cultural areas have already declined due to soil erosion. In this situation, it is important to establish measures of soil conservation in order to reduce land degradation and to assure a sustainable management of soil resources. The implementation of these measures has to be preceded by a spatially distributed erosion risk assessment $[13,14]$. Most advanced figures in Morocco are mainly based on silting of existing dams; measures of the turbidity of runoff and indices of risk of erosion [15-17].

A reconnaissance study showed that for 22.7 million hectares assessed, 8.2 million hectares (36\%) are cultivated of which $18 \%$ requires severe measures of soil conservation; 13.4 million hectares (59\%) should be enhanced by grazing and forest and 1.1 million hectares (5\%) know intense erosion and therefore should be excluded from all agricultural development. So, $64 \%$ of the total area of ponds should not be cultivated [18].

Quantitative studies on erosion processes in Morocco are scarce and mapping erosion risks at a regional scale has not been performed even though general situations of soil-water erosion have been described. All studies carried out before were at sub-watershed and rarely at watershed scales.

The information and data available do not allow mapping of susceptibility of soil to erosion by water across Morocco. However, an attempt to classify the erosion risk based on a combination of three factors (topography, soil and substrate, aggressive climate) has distinguished seven physiographic regions. The average western and southern Rif Mountains are the most exposed to erosion.

In the Rif Chain (Northern Morocco), several local studies have been applied to evaluate and quantify the erosion risk, especially in the western and central Rif [19-25]. The Chain, to which belongs our study area, is generally constituted of limestone and friable formations as marls, shales and flyschs. It shows a complex of poorly evolved soils, resulting from crude minerals, brown soils and soils with Iron/Manganese sesquioxides [18]. It is systematically exposed to torrential rains. Its plant cover has suffered from an intense deterioration during these last decades, because of the rising demographic pressure (overgrazing and land reclamation) and from a sequence of several years of drought [25].

AN ANALYSIS BY PHOTO INTERPRETATION OF 280 HECTARES IN THE Central-western Rif showed that the forest and scrubland, respectively regress of 989 ha/year and 2858 ha/year. At current rates of clearing in this area, and according to socio-economic situation, the forest and matorral would disappear respectively around the year 2014 and 2019 [18].

In this context, it is necessary to develop a soil erosion model based on factors influencing soil-water erosion at regional scale and to establish soil conservation measures which can reduce land degradation and assure a sustain- able management of soil resources preceded by a spatially distributed erosion risk assessment [13,14].

The objective of this study is to provide a map of soil sensitivity to erosion of a representative region of the north of Morocco, the Laou watershed case study, and to evaluate its accuracy.

Being a wide area, it was evident to opte for the georeferencing of the most meaningful parameters which are involved in the erosion process, such as: topography, lithology, geomorphology and land use. Thus, a specific database has been built for each one of these affecting factors using a GIS platform.

The developed model is already applied successfully to soil erosion modelling at various scales when detailed input data are unavailable [26-33]. It uses qualitative decision rules and hierarchical organization of the available data, represented by various thematic maps established from data of basic environmental parameters (such as geology, geomorphology, land cover, slope, and annual rainfall).

\section{The Laou Watershed}

The Laou watershed is situated in the Northwestern part of Morocco, precisely at the north central part of the Rif chain also called the High Rif. It is located between $35^{\circ} 29^{\prime} 22^{\prime \prime} \mathrm{N}$ and $35^{\circ} 00^{\prime} 54^{\prime \prime} \mathrm{N}$, and $05^{\circ} 04^{\prime} 16^{\prime \prime} \mathrm{W}$ and

$05^{\circ} 26^{\prime} 05^{\prime \prime W}$ (Figure 1). This watershed of a width of 28 $\mathrm{km} \mathrm{E-W}$ and $47 \mathrm{~km}$ long N-S, drains an area of 939,242 $\mathrm{km}^{2}$ within a perimeter of $168,335 \mathrm{~km}$. It is bordered by the peaks of Jebel Kelti (1928 m) to the west, Soukna $(1800 \mathrm{~m})$ and Tissoukai $(2122 \mathrm{~m})$ to the south-east, Tazoute $(2159 \mathrm{~m})$ to the north-east and the Mediterranean Sea to the north (Figure 2).

The main course of the wadi, which takes the name of the river Laou, covers a distance of $70 \mathrm{~km}$. It stretches from Bab Taza, where it rises at Jbel Tissoukai, then across the limestone ridge to the alluvial plain where it flows into the Mediterranean. Most tributaries receive low flow, the most important are: O. Tassikesté, O. Farda, O. Kalâa, O. Essarem, O. Talambote, O. Moulay Bouchta, O. Wara and O. Maggo. This latter is the headwaters of Laou. It occupies the lower western slopes of Jebel Lakraa (the highest summit of the limestone ridge) (Figure 1).

Concerning geology, the study area is situated in the axial zone of the Rif chain, which presents a typically mountainous terrain and low plains. The middle and lower courses of the Oued Laou wander through an intra-mountainous old valley, while it originates from the Chefchaouen morphostructure which represents a significant form of the Tingitane peninsula [34-39].

In the upper and lower basin, there is a predominance 


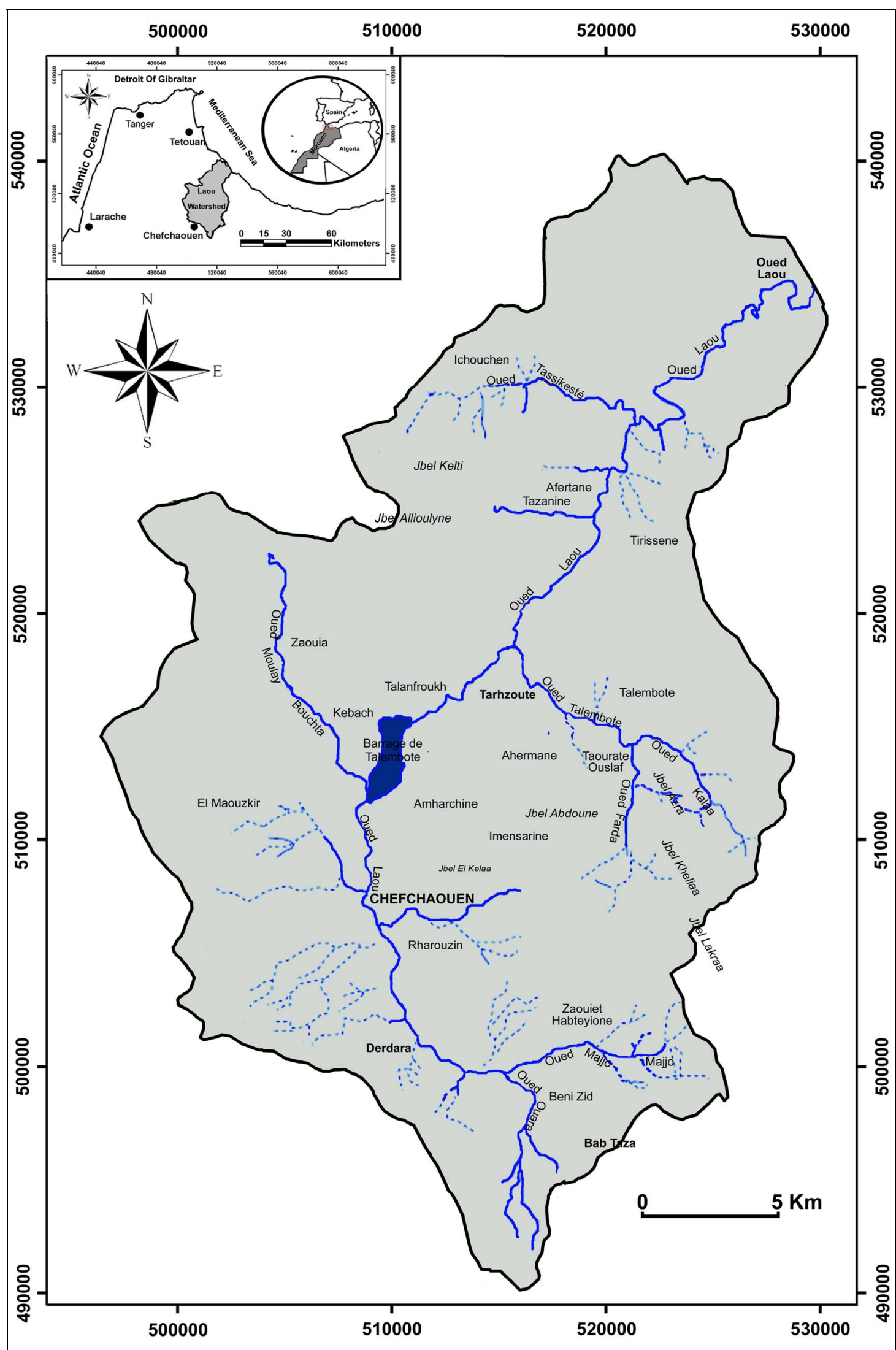

Figure 1. Geographical situation of the Laou watershed. 


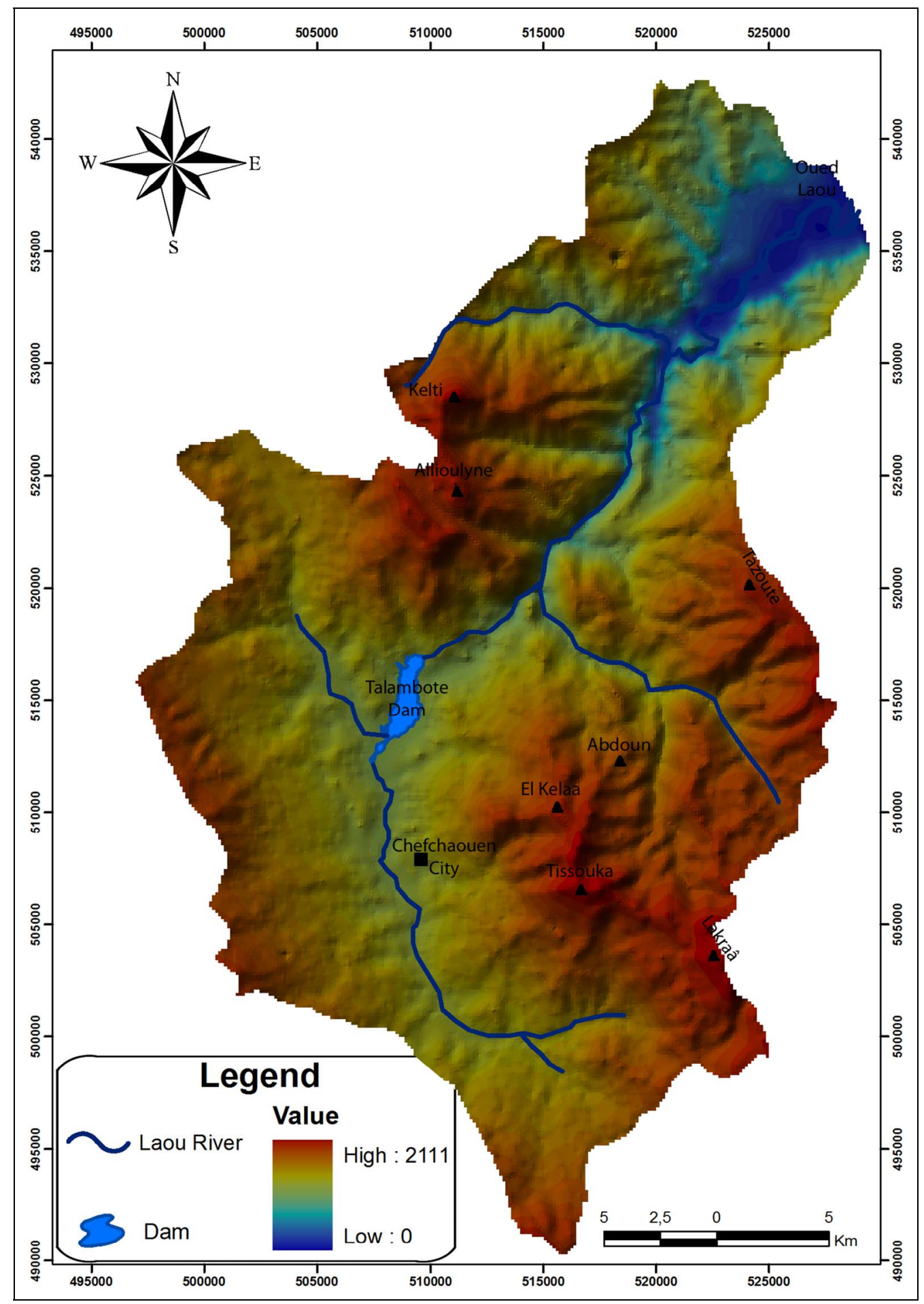

Figure 2. Digital elevation model of the Laou watershed.

of the flysch formations, mainly in the upper one [35, 40-42]. Moving lower, there is the presence of a metamorphic formation represented by the Sebtides unit, constituted by mica-schists, gneiss and peridotites; then, in the north there is the Ghomarides unit, formed mainly by schists. Finally, the alluvial plain and the edge of the wadi is settled into quaternary alluvium and scree [39, 41-44] (see Figure 4).

The relief is generally very articulated, damaged and characterized by steep slopes (Figure 2) except for the downstream coastal plain.

Concerning the climate, the study area has two very 
different types of climates [45]:

- Reliefs have a Mediterranean mountain climate with high winter rainfall (800 and $1400 \mathrm{~mm} /$ year up to about 2000 on the highest peaks), often as snow, and dry warm summers. The recorded temperatures range between $2.3^{\circ} \mathrm{C}$ and $33.8^{\circ} \mathrm{C}$.

- Coastal strip has quite high relative humidity however the precipitations remain lower than the relief $(<500)$, with hotter summers and mild winters. The recorded temperatures have values ranging from $7.2^{\circ} \mathrm{C}$ to $28.6^{\circ} \mathrm{C}$.

The plant cover is very diverse and takes different forms generally divided into forest matorrals, fallow and crops. There are four types of vegetation levels in the watershed of the Oued Laou: the Thermo-mediterranean, the Meso-mediterranean, the Supra-Mediterranean and the Montane-Mediterranean [46-48]. The staging of the altitudinal vegetation is presented by the following keyessential forest timbers: Sandarac or the Barbary thuja (Tetraclinis articulate), Cork Oak (Quercus suber) and Aleppo Pine (Pinus halepensis). In the Talassemtane Park there are other valuable vegetations, well represented by pinsapo Abies, Cedrus atlantica, Fir (Abies maroccana), Cedar (Cedrus atlantica), Holm Oak (Quercus rotundifolia) and maritime pine (Pinus pinaster subsp. hamiltonii) [49,50]. In relation to waterways, there are specific species such as riparian (83 woody species inventoried) [45-49,51].

The principal activities of this region are mainly the agrarian sector and agriculture in particular, followed by livestock. The rest of economic activities, such as Industry, handicrafts, commerce, etc. are not well-developed except for tourism sector. This latter is relatively important especially in Chefchaouen town.

\section{Methodology}

In recent years, methods for assessing and mapping water erosion effects are associated with GIS and remote sensing. It is true that, with these modern techniques, it is gradually discovered the interests of spatialization methods for assessing and mapping soil erosion over large areas and creating scenarios for rehabilitation.

Many studies and techniques implemented around the world were done about potential soil loss calculation. Most of them were based on Universal Soil Loss Equation (USLE) and its revised version (RUSLE) [52]. Others had modified part of the equation to fit in every country's situation. In this study, we tried to fast-track the process using the capabilities of GIS.

In most soil and hydrologic simulation models, several input parameters are required and their derivation can be a complex task depending on variability of the landscape. Researchers have successfully interfaced these models with GIS platforms to assist in the generation of input data sets, in the model execution and in the output of results [53,54]. The use of the GIS technologies makes the application of these models easier since their input parameters could be generated from geographic databases and also, the results could be generated as a cartographic output for better interpretation. On the other hand, the raster data format used in most GIS to synthesize and analyze spatial data makes their use with distributed parameter soil models very practical [55].

In the developing nation like Morocco, collecting ample information is very difficult due to lack of expert engaged in such works and the lack of sophisticated equipments to be used nationwide.

Our study area is characterized by a complex landscape: it presented by a mosaic of landscape units, each one can react differently to the erosive action of water. Mapping of soil sensitivity to erosion using one of these methods of soil loss is very difficult and requires heavy investment especially for large areas, there's also the lack of rainfall data because of scarce climate stations in the study area. Thus, the tool was designed to accommodate and use the currently available data in the study area.

The sensitivity of a terrain to erosion is strongly dependent of its soil nature, vegetation and topographic characteristics. These factors vary greatly at a catchment or regional scale.

All the factors of water erosion are geographic. Therefore, the cartography of these factors could be done easily and efficiently using GIS with various data layers representing watershed boundary, slope, land use, and soils. The combination of this data layers allows the assessment of soil sensitivity to erosion per pixel unit.

This study was undertaken to explore the application of GIS technology in the assessment of erosion risk. It represents a first attempt of application at a regional scale in Morocco. The primary objective was to develop readily transferable GIS-based maps to be used by land resource managers in order to evaluate agricultural land management and conservation practices in terms of soil loss potential.

Geoinformation data was collected and compiled using GIS techniques. The GIS was used to prepare required spatial data, to extract input parameters for the model, to execute the model computations and to display results and maps. All relevant information can be input, stored, processed and analyzed in the GIS system. The output can be used by decision-makers for sustainable land use planning and sustainable land management at local and regional scales.

The developed model (Figure 3) uses qualitative decision rules, evaluations and hierarchical organization of the available data, represented by various maps established from data of basic environmental parameters. 


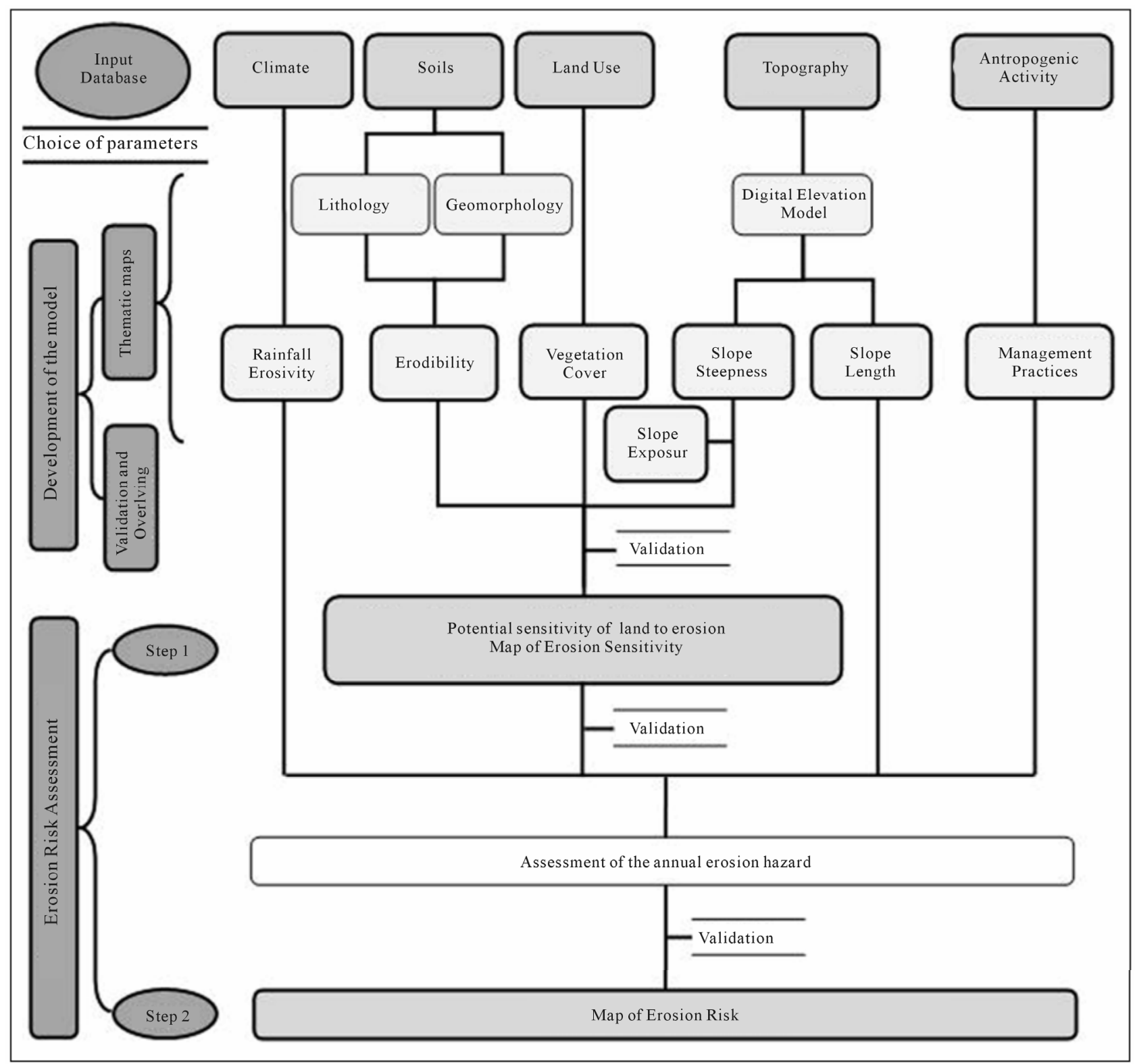

Figure 3. Diagram summarizing the stages of the model.

These latters are hierarchised and weighted on the basis of current knowledge on the different types of functioning erosion.

This is a cognitive model represented as a logical tree where each crossing of factors leads to several possible results, each excluding the other.

The choice of a tree-type decision model requires ranking of each parameter. We gave priority to the factors which have the most important action. The entry order have been defined from literature, experiments and expert's decision, giving the "geo-topo-landuse" sensitivity to erosion to each pixel. These factors, according to the rule-decision, have been linked successively into five classes (very low, low, average, high and very high).
For each combination of these factors, the sensitivity of land to erosion thus defined, is increased or decreased based on an index combining geology, topography and land use.

For each type of geological formations, are given a class of slope (Table 1), and a class of land use (Table 2) (Figure 4). For example, on a very hilly land (very high sensitivity: 5) and an agricultural area (average sensitivity: 3), the risk of erosion is very high when the soil is sandy (high sensitivity: 5) and low when the land is occupied by limestone (very low sensitivity: 1 ).

After the different factors' database is rendered into GIS layers and the empirical model is implemented, the assessment of the potential sensitivity of land to erosion 
Table 1. Classes of lithology and their sensitivity to water erosion.

\begin{tabular}{ccc}
\hline Classes & Type of lithology & Sensitivity to erosion \\
\hline 1 & Limestone & Very weak \\
2 & Quaternary sandstone & Weak \\
3 & Schist and Gneiss & Average \\
4 & Flysch and marls & Elevated \\
5 & Sand & Very elevated \\
\hline
\end{tabular}

Table 2. Classes of land cover and their sensitivity to water erosion.

\begin{tabular}{ccc}
\hline Classes & Type of land cover & $\begin{array}{c}\text { Sensitivity to } \\
\text { erosion }\end{array}$ \\
\hline 0 & $\begin{array}{c}\text { Urbanized areas } \\
\text { bare rocks } \\
\text { Prairies and grazings, } \\
\text { forests and Shrubby zones } \\
\text { Agroforestory zones, } \\
\text { permanent cultures }\end{array}$ & Vull \\
3 & $\begin{array}{c}\text { Very Weak } \\
\text { heath and Schrubs } \\
4\end{array}$ & $\begin{array}{c}\text { Damaged natural zones } \\
\text { degraded forests }\end{array}$ \\
5 & Opened areas and Bare soils & Average \\
\hline
\end{tabular}

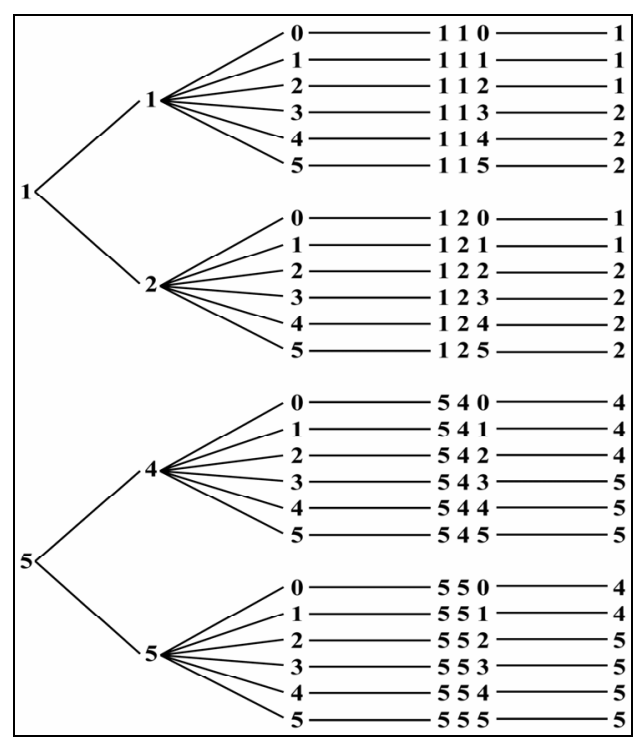

Figure 4. Decision tree model: example of the functioning of different parameters codes.

is determined from the intersection of information layers concerning soil types, land cover and slopes' morphology. The result, which is the main objectif of this paper, is to develop a map of erosion sensitivity.
Even in its reduced form as described above, this model logically merges between the classes assigned to each erosion parameter on any spatial unit. Following the resulting combinations, it may be spatially assigned the grade of sensitivity.

After gridding the various layers, according to the $25 \times$ 25 m pixels of the interpolated Digital Elevation Model (DEM, Figure 2) we allot, to each pixel-unit, classes of land use, of erosion sensitivity and of slope gradient (in percentage).

By the cumulated effect of these affecting factors, we may assign the potential sensitivity to the erosion of any surface unit, within one of 5 grades ranked as: very weak, weak, average, elevated and very elevated.

Thus, the rendered map outputs a qualitative spatially distributed degree of the on-site soils sensitivity to be mobilized, per effect of the soil-erosion factors summarized as above.

\section{Assessment of the Erosion Factors}

The thematic maps of the catchment required for derivation of soil erosion parameters are contour maps, stream network, land cover maps and soil maps. The contour map was obtained through digitalization using GIS Arc/ Info. Using the same procedure, drainage network was also digitized. From topogrid command in ArcGis, the two thematic maps were used to develop a digital elevation model (DEM) for the catchment. A toposheet of 1:50.000 was used in the digitalization of both contours and drainage network. The scanned topographic maps were geometrically corrected by using ten control points such as the graticule intersections in terms of geographic projections into Merchich as datum. The total catchment area of Laou river basin was delineated considering topographical parameters derived from Digital Elevation Model and drainage network and then, digitized boundary layer coverage was developed. ArcInfo GIS were used for generation of various thematic layers namely contour Soils map, drainage map, land use/land cover map and other data sets of the study area.

A digitized contour coverage of $10 \mathrm{~m}$ interval was developed from the topographic map. The digitized contours were given ID (identity) number representing contour elevations. The digitized watershed along with contours was topographically built to create the database table and then, to create a cell size Digital Elevation Model (DEM) of $25 \times 25 \mathrm{~m}$ pixel unit, considered as basic operational unit for the erosion analysis.

\subsection{Soils}

A soil-map for this region was not available, so we had to build-up this layer in order to apply the model. Thus, 
we mapped the geology and the geomorphology of the land, completing it by field observations and lab-results on samples taken from different soils and lithological units collected at the basin. The result is not a soil-map in the strict sense, but a geological map where we assigned erodibility factors to the different geological formations. Geomorphology has served us to identify screes and, in general, areas likely to be more easily erodible.

\subsubsection{Lithology}

The nature of surface materials plays a very important role to identify the areal sensitivities to erosion.
Since geology was not available in digital format, the lithology was determined from different geological maps of Chefchaouen [56], Bab Taza [57], Talembote [58] and Beni Hassan [59] available at 1:50.000 scale. Depending on the nature of different rock types, the classification was based on several studies [60,61], but with adaptation to local conditions of the study area.

The lithology of the Laou basin shows strong resistance in the limestone dorsal and the paleozoique formations (Sebtides and Ghomarides) and medium in the flysch nappes, while high erodibility is expected into Quaternary deposits and alluvium (Figure 5).

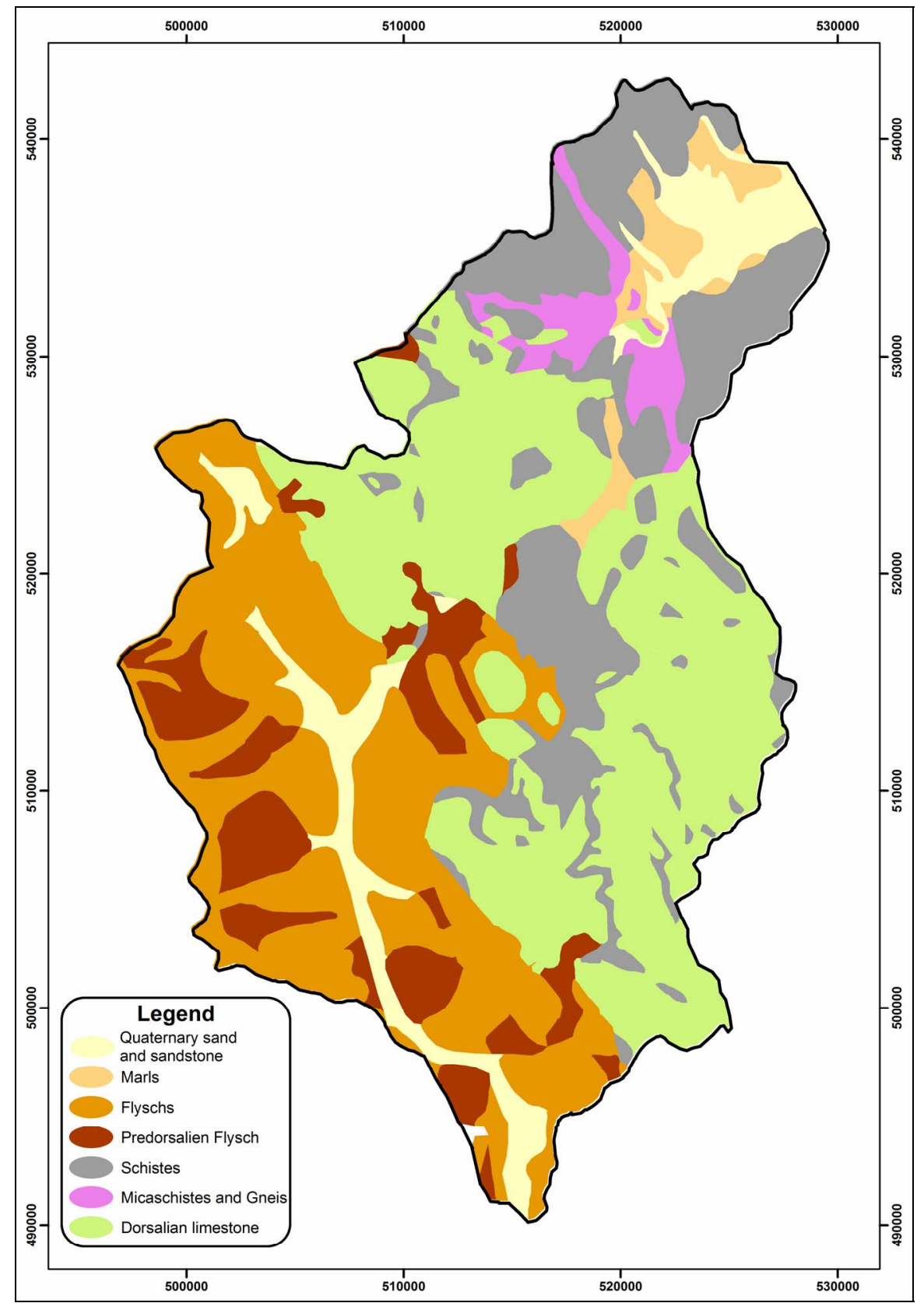

Figure 5. Lithological map of the Laou watershed. 
In Table 1, are presented different types of surface lithology and their sensitivity to water erosion.

\subsubsection{Geomorphology}

A Geomorphological factor is defined as the way of involvement of different geological formations morphology in the risk of erodibility, namely: the presence of areas of scree, landslides and some particular morphologies of the existing geological formations in the basin.

This information layer was again produced by scan- ning and digitizing the geomorphological map of the region, then a subsequent harmonization of the different characters was applied.

The geomorphological map shows the presence of landslides and debris, especially in the river borders, in zones close to the dam and in areas with steep slopes (Figure 6). The erodibility factor of each litho-soil unit may then increase or decrease when this layer of information is overlapped to the previous one depending on the essential nature of the geomorphological fields.

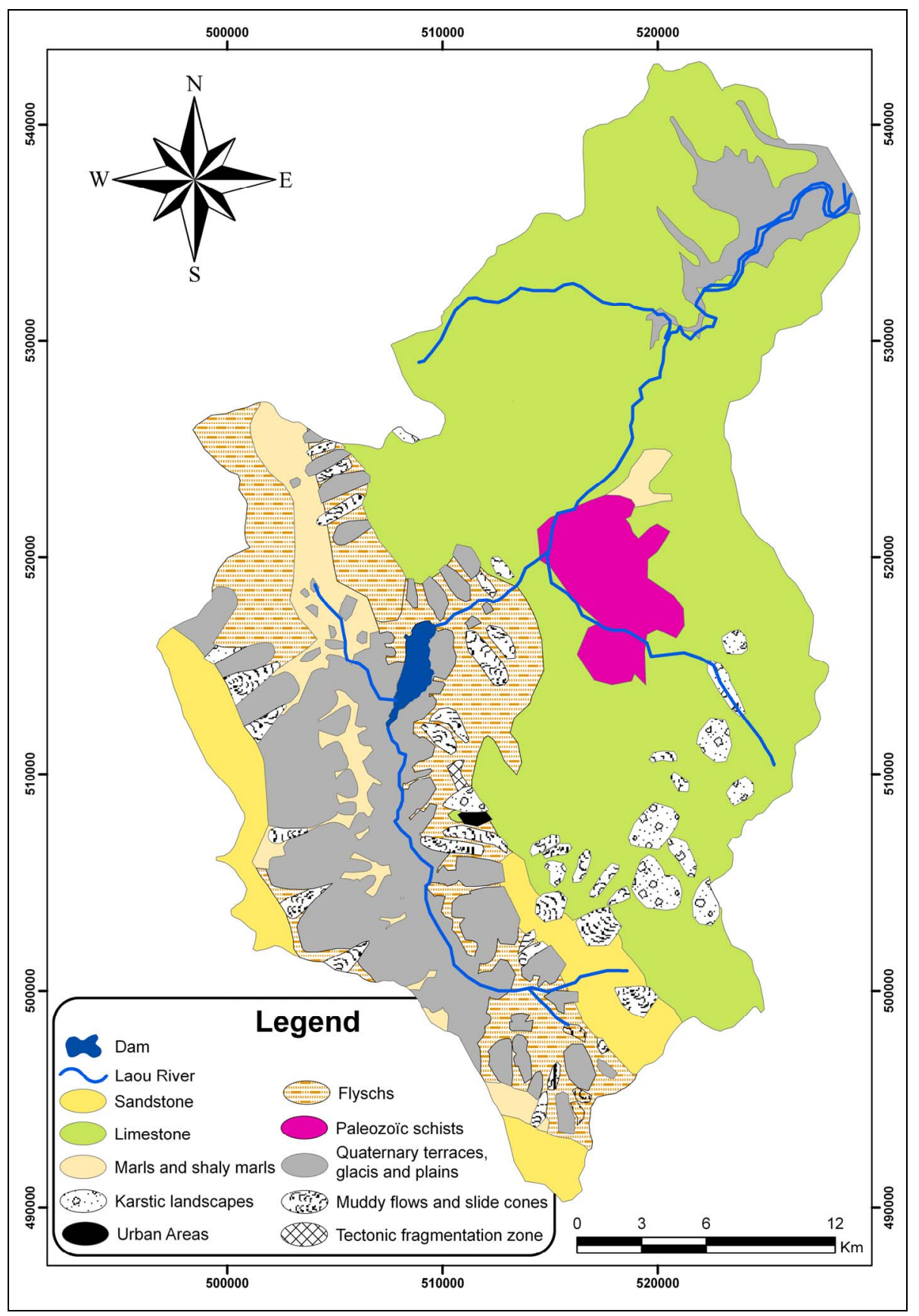

Figure 6. Geomorphological map of the Laou watershed. 


\subsection{Land Use}

The canopy state affects largely the soil erodibility. A healthy cover of vegetation assures soil stability, constituting natural protection against erosion.

The employed map of the land use was developed by the Ministry of Environment in 2004. This map, created with a list of 33 basic classes, was updated and reclassified into 10 classes per their different behaviour with respect to the erosion processes (Figure 7).

The 10 classes of land use are defined as follow:

1) Urbanized areas: those for which the erosion proc- esses are dependent on further developments;

2) Permanent cultures: yearly and/or permanent cultivations, associated to irrigated perimeters;

3) Agro-forestry zones;

4) Natural damaged zones: spaces in mutation by the disappearance of vegetation; these spaces may be susceptible to erosion on unstable materials because the soil can be exposed to very steep slopes;

5) Heterogeneous agricultural zones: involve quite different units but forming contrasting landscape (piecemeal fragmented and diverse mosaic of cultures, alternating

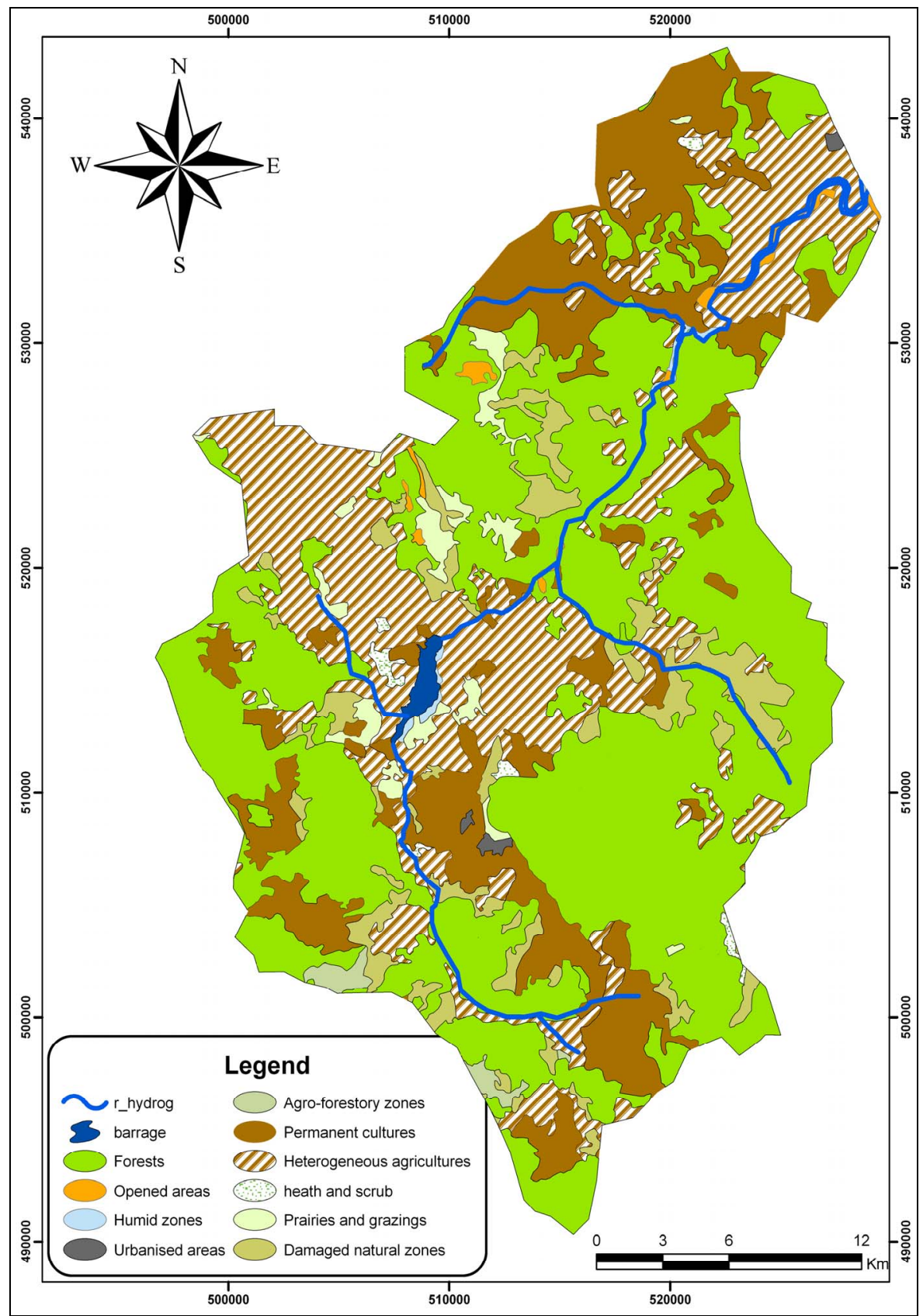

Figure 7. Map of the land use classes. 
meadows, farmland and woods); this diversity is a factor limiting the runoff, compared to open areas such as arable land;

6) Heath and shrubs: where the landscape is characterized by open low-growing woody vegetation, mostly consisting of heaths, heathers and related species;

7) Prairies and grazings: here the land surface has good protection thanks to an encouraged infiltration;

8) Humid zones: including areas of open water (seas, lakes, rivers) and wetlands (marshes and rice fields);

9) Opened areas: arable earths without vegetation which can be practically naked during a long period of the year. Its regroups also bare rocks, glaciers, dunes and beaches;

10) Forests and shrubby zones: having little appreciable erosion effects, except on the very steep slopes and the unsteady lands).

The classification of different modes of land use (Table 2) according to their sensitivity to water erosion has been established as a result of field observations and consultation of several bibliographical studies [4,62-64].

The risk of water erosion is null in dense urban areas (soil present in small quantities or absent) and on resistant rocks. But in both cases, the transport of water and siltation downstream are promoted.

The well maintained forests are considered as insusceptible to water erosion. Indeed, the permanence of vegetation, leaves and branches of trees, absorbs the impact of raindrops. The root system maintains the cohesion of the soil and Plant litter, which improves the structure of the surface horizons of the soil, making them more permeable to water.

Water erosion is highest in bare soils without protection against water [11].

The basin vegetation allows us to indicate a high erodibility in the non-wooded land and a low one in the forest populated by Mirbeck's Oak, Holm oak and cork oak, which are more resistant to erosion.

\subsection{Surface Morphology}

The digital elevation model (DEM) represents the spatial variation in altitude, A Digital Elevation Model was produced from the manual digitalization of the contour lines from the available $1 / 50.000$ scale maps.

The cell size of $25 \mathrm{~m}$ was selected and watershed boundary layer was overlain by the generated grid coverage. All the uniquely identified cells (numbered consecutively from the northwest to southeast corner and proceeding from west to east) with less than $25 \%$ of the area overlying the watershed were excluded.

The obtained DEM (Figure 2) may be considered of good quality and define the basic pixel unit, common to all the information layers.
The use of this DEM has allowed us a better gradient estimation for steeply marked terrains or for areas with short hilly slopes. Very important outcomes from this basic layer are represented by the extraction of the derivative maps of the slope and length classes, the exposure and the hydrological map.

Slope is one of the important factors causing soil erosion. A steep rising slope is responsible of increased erosion [53], still it is not always the main factor. Nine major classes of slopes were distinguished. The length of the slope could not be taken into account in this study. According to Gay [65] and FAO [66], this parameter would not have a primary importance in the Mediterranean regions.

The slope map was generated using Triangulated Irregular Network (TIN) developed from contour coverage employing ArcGIS 9.3.

The average slope of each grid unit is calculated, in (\%), from the difference in altitude with respect to its 8 neighbours. The slope values were grouped into 8 classes: $0 \%$ - 1\%; 1\% - 2\%; 2\% - 5\%; 5\% - 10\%; 10\% - 15\%; $15 \%$ - 30\%; 30\% - 75\%; $>75 \%$ (Figure 8). These boundaries were selected on the basis of the real field values and observations and according to what has been referred in the current literature.

The slope classes can be reduced to five as like as the other factors and in order to apply the model. In the following table (Table 3) are represented the five classes of sensitivity to erosion attributed to the different slope classes.

\section{Application of the Model}

Each layer of information is first transformed in raster mode, according to the basic pixel of the DEM to normalize the different scales of the data sources and thus obtaining an overall homogeneous cross-spatiality.

After gridding the thematic maps of parameters involved, we have performed the superposition of the information layers on soils, land cover and terrain, to get the potential sensitivity to erosion per spatial unit.

\subsection{Cartographic Superposition}

The digital superposition of these parameters allowed us

Table 3. Classes of slope and their sensitivity to water erosion.

\begin{tabular}{ccc}
\hline Classes & Classes of slope & Sensitivity to erosion \\
\hline 1 & $0-2$ & Very weak \\
2 & $2-5$ & Weak \\
3 & $5-15$ & Average \\
4 & $15-30$ & Elevated \\
5 & $>30$ & Very elevated \\
\hline
\end{tabular}




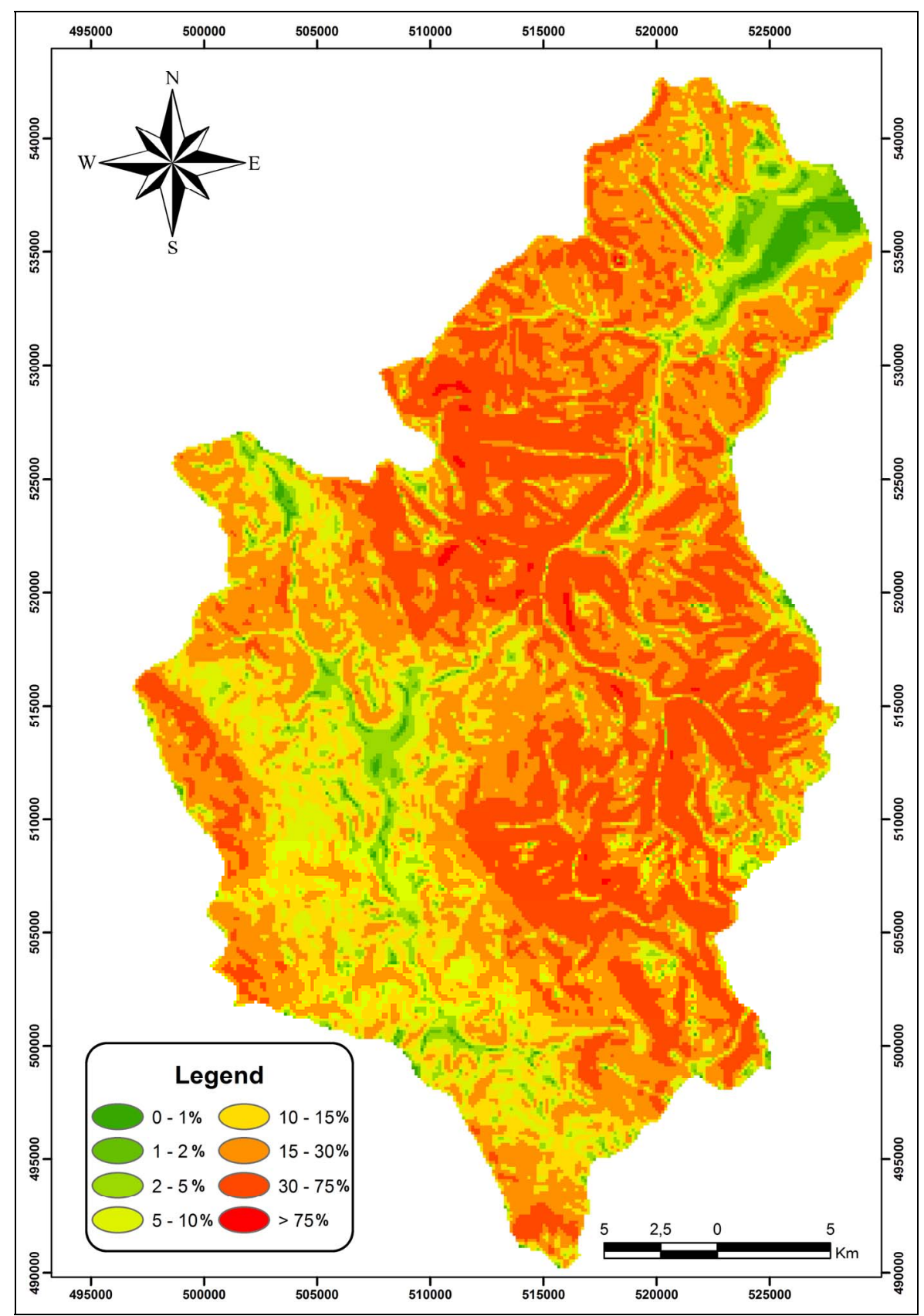

Figure 8. Slope classes map.

to draw a map of the potential erosivity in the catchment area of Laou River. Thus, each layer has been subdued to a change of variable process, which transformed them into a descriptive index of sensitivity.

The gridding and the superposition of the relevant layers (i.e. slope, land use, lithology and geomorphology), allowed us to identify those areas at high risk of erosion. The rendered map (Figure 9) outputs qualitative information on the distributed sensitivity degree of the on-site soils to be mobilized by the water erosion factors.

Thus, by the cumulated effect of these affecting factors, we may assign the potential sensitivity to the erosion of any surface unit, within one of 5 levels.

The obtained results, assessed by a spatial exploration on the different parameters' layers, show that a severe erosion affects the Southern and North-Western sectors of the basin which are, by the way, represented by very damaged and steep slopes. These particular morphologies motivate the great sensitivity to erosion, even if they present the least erodible lands of the entire basin (formations of the calcareous dorsal) and have, as well, a relatively dense plant cover. Other negative factors are 


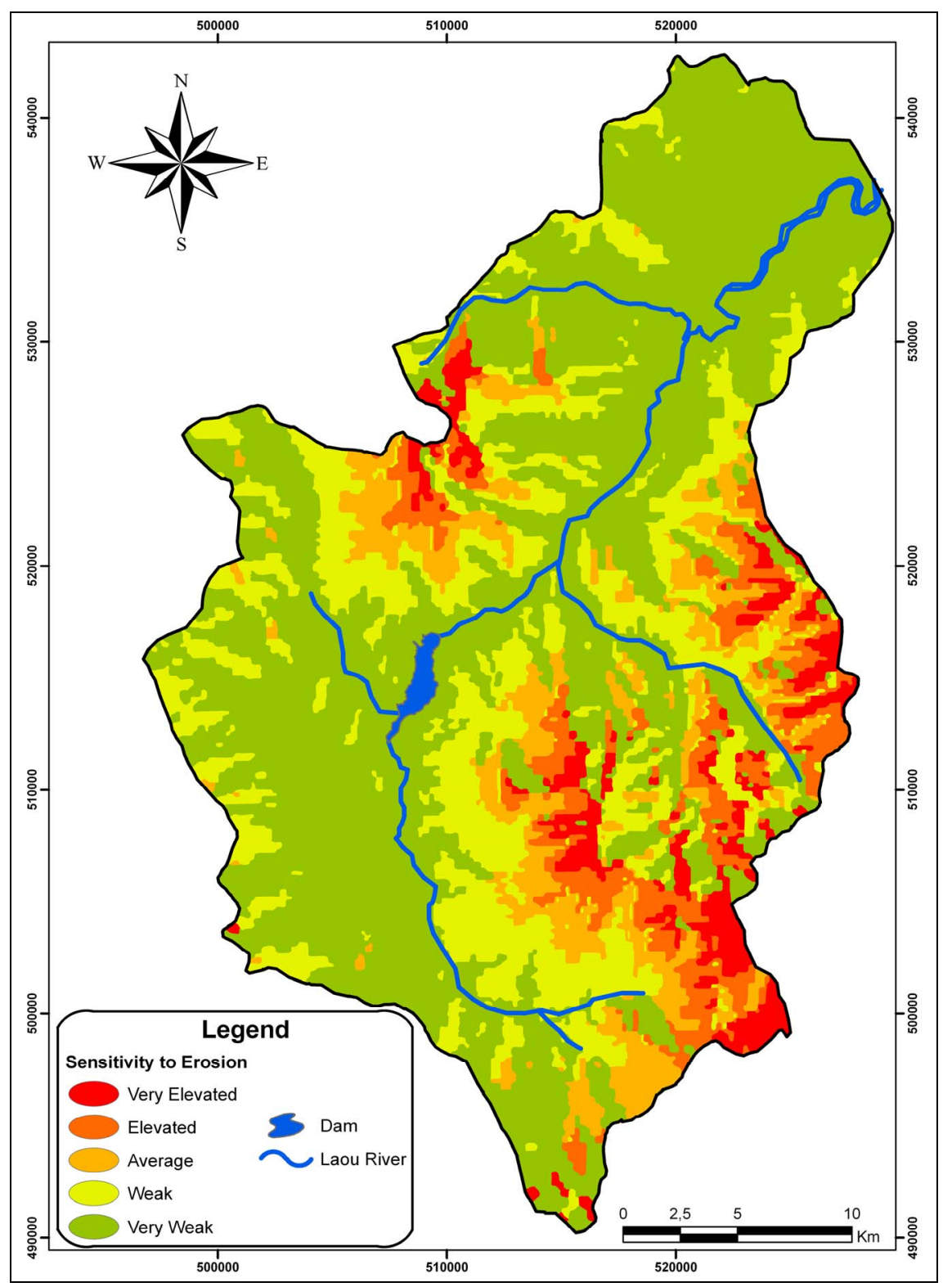

Figure 9. Potential risk of erosion in the Laou watershed.

represented by the fact that this mountainous range is systematically exposed to torrential precipitations, dominant winds and to long periods of harsh solar radiation.

In the other zones of the basin, in spite of the presence of less competent soil covers (essentially alluvia, shales and flysch) and a much more sparse vegetation, the sensitivity to the erosion stays from weak to middling, allowing thus to conclude that the high gradient and damaged terrain state represents the main factor of water erosion in the Laou Watershed, triggered by the concurring climatic actions too.

\subsection{Validation of the Results}

The modelling of the erosion process is an important and strategic work, therefore it needs strict procedures of validation and, if regional structures are involved, the establishment of a fairly large scale is required.

The validation may be done in two ways:

- A comparison with other results and/or other data sources: this is not possible in our case, because similar analyses or data outputs are not available;

- An examination of the inherent errors due to the empirical model.

In order to highlight the errors and imprecision intrinsic to the model, another possible consideration would consist of an analysis of the error propagation during the various treatments in the geographic information system. This was obtained by estimating the uncertainties for 
each layer of information, and then to evaluate their accumulation within the expert system.

\subsection{Advantages and Problems of the Model}

Our model has defined a map of sensitivity to erosion with six classes for a representative watershed in Northern Morocco, as a first attempt to generalise this study at a regional scale. Such map is unavailable in Morocco, although at this stage the map depends on qualitative and relatively subjective procedures. The map represents the result of modelling from available knowledge and data and can meet scientific needs of researchers as well as socioeconomic demands of decision makers. This model can be extrapolated to the whole country if the functional capacities of GIS are used, because they allow model integration with additional basic and factorial data and code modification in order to analyse the data. At the same time, the thematic and derived maps can be updated and evaluated to assure precision before executing the model and obtaining the final map of sensitivity to erosion.

There is also the need and the possibility of integration of new factors in the model, e.g. rock infiltration capacity, the consideration of sedimentation zones, tectonic fragmentation, splash effects, etc. However, that needs a lot of work and many difficulties will be encountered [28].

\section{Conclusions}

In terms of erosion, there are always two risks involved. On one hand, there is loss of land, which constitutes a loss of thickness of the soil cover: this is a risk if man uses the soil resource for production (crops, forests, etc.) or for reserve (water retention, application of sludge, waste products etc.). On the other hand, the risks due to erosion can be designed as a landing ground in various places where it is undesirable (urban areas, greenhouses, roads, railways or waterways, etc.). In the first case, the risks are mainly located upstream whereas in the second they are downstream. Therefore, we must introduce the concepts of "upstream/downstream" in relation to the risk of "loss/landing" of soils when addressing wide areas of study [11,26].

An important tool has been developed, in the form of a cognitive model which applies simplified rules, qualitative evaluations and parameters ranking. It is a flexible model that may be rather easily modified during an update of the information layers, which allows to obtain an, as objective as possible synthesis of the erosive phe- nomena. It permits the choice of different spatial resolutions, in order to calibrate the presentation of its results to the needs of decision makers at different scales.

The multi-source approach, combining terrain, lithology, geomorphology and land use in a GIS, applied to the catchment area of the Laou River, allowed us to identify those arable surfaces which require highest priority interventions for the protection of soil and, not of least importance, the reduction of sediment transportation at the dams.

The proposed model aims to treat large spatial fields. The overall approach proposed can feed the many existing local experiments, but it raises other issues related to spatial extrapolation. This latter cannot be based solely on local studies. It must take into account the local multiple geographies and provide a summary. It must consider local circumstances and arrangements of their spatial organization. For example, an erosion zone located upstream of an area without erosion has different conesquences, in the overall geographic approach, as an erosion zone located downstream of an area without erosion. The method of landscape analysis based on laws can be attempted [67].

In addition, the use of GIS allows the integration at any time new spatial data and allows the development of small-scale management plans that is sufficient to estimate the areas vulnerable to water erosion for a political overall protection of these areas.

However, it must be noted that detailed field verification is still needed to identify the sectors showing inaccurate results by the model (possibly due to change of state or after intrinsic errors); this phase may also allow to recognize the eventual sources of error and to continually update the database.

During the development of the model, the major difficulties has regarded the acquisition of the information needed to implement the database, being soil types the topmost, followed by the height/intensity of rainfall and the length of slopes in karstic zones, or very hilly areas.

Nevertheless, the integration of this partial "USLE" model into a GIS has shown many advantages, especially those related to the results which rise evidence on the local factors involved in the erosion process. GIS allows rational management of a multitude of data, with respect to the various factors responsible of land degradation; in fact, in this case, it permitted us to conclude that the main factor in the Laou watershed are the steep and damaged slope morphologies, followed by the soil erodibility and the vegetation cover. GIS also allows a rather easy enrichment and continuous updating of the database.

On the other hand, in the absence of an intensive monitoring program, it is generally impossible to recognize the precision of the estimates obtained by such models. Even if restricted by this adverse situation, we may say that, by comparison to more localized studies that were realised in the region or in other parts of the Mediterranean, the estimates provided by this model are mostly acceptable and the spatial distribution of the water erosion risk seems reasonable and fair. 


\section{Acknowledgements}

This study was conducted in partial fulfillment of a MSc degree on Geo-Environment at the Faculty of Sciences and Technologies of Tangier (Morocco). The presented research has been supervised also by other Professors, with special thanks to Pr. Miriam WAHBI. ${ }^{1}$

All the co-authors contributed to the writing of this paper.

\section{REFERENCES}

[1] E. Z. Nyakatawa, K. C. Reddy and J. L. Lemunyon, "Predicting Soil Erosion in Conservation Tillage Cotton Production Systems Using the Revised Universal Soil Loss Equation (RUSLE)," Soil and Tillage Research, Vol. 57, No. 4, 2001, pp. 213-224. doi:10.1016/S0167-1987(00)00178-1

[2] G. R. Foster and L. D. Meyer, "A Closed-Form Soil Erosion Equation for Upland Areas,” In: H. W. Shen, Ed., Proceeding of Sedimentation Symposium to Honor Prof. H. A. Einstein, Colorado State University, Fort Collins, Vol. 12, 1972, pp. 12.1-12.19.

[3] S. Kuznetsov, U. Feudel and A. Pikovsky, "Renormalization Group for Scaling at the Torus-Doubling Terminal Point,” Physical Review, Vol. 57, No. 2, 1998, pp. 15851590.

[4] J. Poesen and J. Hooke, "Erosion, Flooding and Channel Management in Mediterranean Environments of Southern Europe,” Progress in Physical Geography, Vol. 21, No. 2, 1997, pp. 157-199. doi:10.1177/030913339702100201

[5] J. D. Phillips, "Hillslope and Channel Sediment Delivery and Impacts of Soil Erosion on Water Resources," International Association of Hydrological Sciences (IAHS) Publications, Vol. 23, No. 184, 1989, pp. 183-190.

[6] P. A. Idah, H. I. Mustapha, J. J. Musa and J. Dike, “Determination of Erodibility Indices of Soils in Owerri West Local Government Area of Imo State, Nigeria,” Assumption University Journal of Technology, Vol. 12, No. 2, 2008, pp. 130-133.

[7] G. Brhane and K. Mekonen, "Estimating Soil Loss Using Universal Soil Loss Equation (USLE) for Soil Conservation planning at Medego Watershed, Northern Ethiopia,” Journal of American Science, Vol. 5, No. 1, 2009, pp. 58-69.

[8] L. Oldeman, R. Hakkeling and W. Sombroek, "World map of the Status of Human Induced Soil Degradation, an Explanatory Note," Global Assessment of Soil Degradation GLASOD, 1st Edition, International Soil Reference and Information Center, Wageningen, United Nations Environmental Program-I11, Nairobi, 1990, 41 p.

[9] S. D. Angima, D. E. Stott, M. K. O’Neill, C. K. Ong and G. A. Weesies, "Soil Erosion Prediction Using RUSLE for Central Kenyan Highland Conditions,” Agriculture, Ecosystems and Environment, Vol. 97, No. 1, 2003, pp.

${ }^{1}$ LEORN: Laboratory "Environnement, Océanologie et Resources Naturelles”, Department of Geology, Faculty of Sciences and Technologies of Tangier, Abdelmalek Essaâdi University, Morocco.
295-308. doi:10.1016/S0167-8809(03)00011-2

[10] D. C. Pimental, "Environmental and Economic Cost of Soil Erosion and Conservation Benefits," Science, Vol. 267, No. 5201, 1995, pp. 1117-1123. doi:10.1126/science.267.5201.1117

[11] R. Bou Kheir, M. C. Girard, M. Khawlie and C. Abdallah, "Water Erosion in Mediterranean Environments: A Bibliographic Review,” Soil Survey and Management, Vol. 8, No. 4, 2001, pp. 231-245.

[12] CEC (Commission of European Communities), “Communication from the Commission to the Council, the European Parliament, the Economic and Social Committee and the Committee of Regions: Towards a Thematic Strategy for Soil Protection,” Final Report, Bruxelles, 2002.

[13] R. Moussa, M. Voltz and P. Andrieux, "Effects of the Spatial Organization of Agricultural Management on the Hydrological Behaviour of a Farmed Catchment during Flood Events," Hydrological Processes, Vol. 16, No. 2, 2002, pp. 393-412. doi:10.1002/hyp.333

[14] V. Souchère, O. Cerdan, N. Dubreuil, Y. Le Bissonnais and C. King, "Modelling the Impact of Agri-Environmental Scenarios on Overland Flow in a Cultivated Catchment (Normandy, France)," Catena, Vol. 61, 2005, pp. 229-240. doi:10.1016/j.catena.2005.03.010

[15] FAO, "Erosion Control and Soil Conservation in Morocco. Analysis of Erosion Problems at National Scale," Report Based on the Works of the Project Team of Experts, Rome, 1975.

[16] H. M. J. Arnoldus, "Prediction of Soil's Losses by Sheet and Claw Erosion. Watershed Development," FAO Soils Bulletin: Soil Conservation, 1977, pp. 121-149.

[17] N. Boutayeb, “Impact of Watershed's Degradation on National Economy," Proceedings of the National Seminar on Watershed Development, 18-23 January 1988.

[18] MINENV, "Report on the State of the Environment in Morocco," Secretariat of the State Charged of Water and Environment, Department of Energy, Mines, Water and Environment, Morocco, 2001, 292 p.

[19] B. Heusch, "Prerif Erosion. A Quantitative Study of Water Erosion in the Marly Hills of the Western Prerif," Directory of Forest Research of Morocco, 1970, pp. 129176.

[20] M. Benmoussa, M. El Yamani and A. Saidi, "Application of the Universal Soil Loss Equation in the Oued Tasfare Watershed,” Géo-Observateur, Vol. 3, 1993, pp. 83-93.

[21] A. A. Fora, "Spatial Modeling of Water Erosion in a Watershed of the Moroccan Rif Chain: Validation of the Geomatic Approach Using Sedimentology, Radioactive Tracers and Magnetic Susceptibility,” Ph.D. Thesis, Sherbrooke University, Sherbrooke, 1995, 231 p.

[22] M. Rahhou, "Erosion in the Central Prerif, Interfluviale Area between Leben, Sebou and Ouergha Rivers, an Extension of Natural Evolution, a Social Production,” Ph.D. Thesis, Mohammed V University, Rabat, 1999.

[23] J. Al Karkouri, "Environmental Degradation in the Beni Boufrah Watershed (Central Rif-Morocco): Spatial Analysis and Modeling,” Ph.D. Thesis, University of Moham- 
med V, Rabat, 2003, 392 p.

[24] H. Siteri, L. Aït Brahim, F. Sossey Alaoui, I. Al Hamdouni, N. El Hatimi, M. Labraimi, A. Ammar, B. Baghdad and M. Tahri, "Integration of USLE into a GIS to Determine Specific Degradation of Soils in the Northern Rif (Nakhla Watershed Case Study)," Scientific Institute Bulletin, Rabat, Geology and Physical Geography Series, No. 21, 2003, pp. 241-276.

[25] A. Sadiki, S. Bouhlassa, J. Auajjar, A. Faleh and J. J. Macaire, "Use of GIS for the Evaluation and Mapping of Erosion Risk by the Universal Soil Loss Equation in the Eastern Rif (Morocco): Boussouab Watershed Case Study," Scientific Institute Bulletin, Rabat, Earth Sciences Series, No. 26, 2004, pp. 69-79.

[26] R. Bou Kheir, M.C. Girard, A. Shaban, M. Khawlie, G. Faour and T. Darwich, "Contribution of Remote Sensing for the Modeling of Soil Water Erosion in the Mountainous Coastal Region of Lebanon," Teledetection, Vol. 2, 2001, pp. 1-22.

[27] R. Bou Kheir, M.C. Girard, M. Khawlie, "Using a Structural Classification OASIS for Mapping of Landscape Units in a Representative Region of Lebanon,” Canadian Journal of Remote Sensing, Vol. 30, 2004, pp. 617-630.

[28] R. B. Kheir, O. Cerdan and C. Abdallah, "Regional Soil Erosion Risk Mapping in Lebanon,” Geomorphology, Vol. 82, No. 3-4, 2006, pp. 347-359. doi:10.1016/j.geomorph.2006.05.012

[29] R. B. Kheir, C. Abdallah, M. Runnstrom and U. Martensson, "Designing Erosion Management Plans in Lebanon Using Remote Sensing, GIS and Decision-Tree Modeling," Landscape and Urban Planning, Vol. 88, No. 2-4, 2008, pp. 54-63. doi:10.1016/j.landurbplan.2008.08.003

[30] O. Cerdan, Y. Le Bissonnais, A. Couturier and N. Saby, "Modelling Interrill Erosion in Small Cultivated Catchments," Hydrological Processes, Vol. 16, 2002, pp. 3215-3226. doi:10.1002/hyp.1098

[31] O. Cerdan, V. Souchère, V. Lecomte, A. Couturier and Y. Le Bissonnais, "Incorporating Soil Surface Crusting Processes in an Expert-Based Runoff and Erosion Model STREAM (Sealing Transfer Runoff Erosion Agricultural Modification)," Catena, Vol. 46, 2002, pp. 189-205. doi:10.1016/S0341-8162(01)00166-7

[32] M. T. Harris and J. Boardman, "A Rule-Based Expert System Approach to Predicting Waterborne Soil Erosion," In: J. Boardman, D. L. Foster and J. A. Dearing, Eds., Soil Erosion on Agricultural Land, John Wiley \& Sons, Chichester, 1990, pp. 401-412.

[33] Y. Le Bissonnais, J. Thorette, C. Bardet and J. Daroussin, "Water erosion of soils in France," INRA, IFEN, 2002, $106 \mathrm{p}$.

[34] A. André, "Introduction to Physical Geography of the Tangier Peninsula," Journal of Geography of Morocco, Vol. 19, 1971, pp. 57-75.

[35] P. Fallot, "Essay on the Geology of the Northern Rif," Notes and Memoirs of the Department of Mines and Geological Maps, Vol. 40, 1937.

[36] J. C. Griffon, "The Limestone Ridge in the South of Te- touan," Notes and Memoirs of the Geological Service, Geological Studies of the Rif Chain I, Morocco, No. 184, 1966, pp. 149-212.

[37] M. Leikine, "The Haouz Chain in the North of Tetouan (Jbel Dersa)," Notes and Memoirs of the Geological Service, Geological Studies of the Rif Chain II, Morocco, No. 194, 1969, pp. 7-49.

[38] A. Nold, J. Uttinger and W. Wildi, "Geology of the Limestone Ridge between Tetouan and Assifane (Internal Rif, Morocco)," Notes and Memoirs of the Geological Service, Morocco, No. 300, 1981, 233 p.

[39] P. Olivier, "Evolution of the Boundary between Internal and External Zones in the Arc of Gibraltar (Morocco, Spain),” PhD Thesis, Toulouse I University, Toulouse, 1984, 229 p.

[40] P. Lespinasse, "Geology of External Areas and Flyschs between Chaouène and Zoumi (Central Rif chain, Morocco),” Ph.D. Thesis, Toulouse I University, Toulouse, 1975, $248 \mathrm{p}$.

[41] A. Michard, "Elements of Moroccan Geology,” Notes and Memoirs of the Geological Service, Morocco, Vol. 252, 1976, $408 \mathrm{p}$.

[42] A. Piqué, "Geology of Morocco, the Regional Domains and Their Structural Evolution,” In: Pumag, Ed., Rabat, 1994, 284 p.

[43] F. Belhadad, “Geological Study of the Northern Rif's Internal Zones during the Oligocene and the Miocene. Jbel Zemzem,” Post Graduate Thesis, Mohammed V University, Rabat, 1983, 120 p.

[44] M. Durand Delga, L. Hottinger, J. Marcais, M. Mattauer, Y. Milliard and G. Suter, "Actual Data on the Structure of the Rif Chain,” Out of Series Memoirs, Geological Society of France (Memory Book P. Fallot), Vol. 1, 1962, pp. 399-422.

[45] INYPSA (INformes Y Proyectos SA), "Operational Program INTERREG II Spain-Morocco,” Analysis of the Current Situation, Coordinated Program for the Development, Recovery and Improvement of the Laou Watershed, Morocco, Vol. 1, 1999, 204 p.

[46] A. Benabid, "Knowledge on Moroccan Vegetation: Phytogeography, Vegetation Phytosociology and Series of vegetation,” Lazaroa, Vol. 14, 1994, pp. 21-97.

[47] A. Benabid, "Flora and Ecosystems of Morocco: Assessment and Biodiversity Conservation,” Ibis Press, París, 2000.

[48] A. El Gharbaoui, "Land and Humans in the Tangier Peninsula: Study on Humans and Natural Environment in the Western Rif,” Scientific Institute Bulletin, Rabat, Geology \& Physical Geography Series, No. 15, 1981, 439 p.

[49] M. Ibn Tattou, "Talassemtane National Park: Habitats and Plant Biodiversity,” Unpublished Report, MEDA/MAR/ B7-4100/IB/98/0532, 2005, 48 p.

[50] A. Mokadem, "Talassemtane Park: Strengths, Constraints and Strategy," Proceeding of the Seminar Theory and Practice of Plant Conservation in Southern Iberian Peninsula and Morocco, Tétouan, 2005, pp. 43-44.

[51] A. Chaara, "Agriculture and Fishing in the Rif Coasts,” 
Publications of the Tetouan Asmir Association, Morocco, 1996, 112 p.

[52] K. G. Renard, G. R. Foster, G. A. Weesies, D. K. McCool and D. C. Yoder, "Predicting Soil Erosion by Water: A Guide to Conservation Planning with the Revised Universal Soil Loss Equation (RUSLE)," USDA Agricultural Handbook, No. 703, 1997, pp. 126-131.

[53] R. Srinivasan, B. A. Engel, J. R. Wright, J. G. Lee and D. D. Jones, "The Impact of GIS-Derived Topographic Attributes on the Simulation of Erosion Using AGNPS," Applied Engineering in Agriculture, Vol. 10, No. 4, 1994, pp. 561-566.

[54] S. T. Udoyara and R. Jolly, "Evaluating Agricultural NonPoint Source Pollution Using Integrated Geographic Information Systems and Hydrologic: Water Quality Model,” Journal of Environmental Quality, Vol. 23, 1994, pp. 2535. doi:10.2134/jeq1994.23125x

[55] R. Srinivasan and B. A. Engel, "Effect of Slope Prediction Methods on Slope and Erosion Estimates," Applied Engineering in Agriculture, Vol. 7, No. 6, 1991, pp. 779783.

[56] Anonym, "Geological Sheet of Chefchaouen at 1/50000," Notes and Memoirs of the Geological Service, Morocco.

[57] S. E. M. Saadi, E. A. Hilali and A. Boudda, "Geological Sheet of Bab Taza at 1/50000," Notes and Memoirs of the Geological Service, Morocco, No. 288, 1975.

[58] S. E. M. Saadi, E. A. Hilali and A. Boudda, "Geological Sheet of Talembote at 1/50000," Notes and Memoirs of the Geological Service, Morocco, No. 290, 1975.
[59] J. Diddon, "Geological Sheet of Souk Larbaâ Beni Hassan at 1/50000," Notes and Memoirs of the Geological Service, Morocco, No. 454, 2001.

[60] S. Davis and R. Deweist, "Hydrogeology,” John Willey and Sons Ltd., Chichester, 1966, 463 p.

[61] Z. Beydoun, "Petroleum Prospects of Lebanon Re-Evaluation," American Association of Petroleum Geological Bulletin, Vol. 61, No. 1, 1977, pp. 43-64.

[62] FAO, "Erosion Mapping Using High Resolution Satellite Data and Geographic Information System. Pilot Study in the State of Parana, Brasil," Remote Sensing Center, Rome, 1990, 147 p.

[63] Food and Agriculture Organisation (FAO), "Field Measurements of the Erosion and Surface Water Flow," FAO Soils Bulletin, Vol. 68, 1996, 153 p.

[64] J. Garcia-Ruiz, T. Lasanta, P. Ruiz-Flano, L. Ortiza, S. White, C. Gonzalez and C. Marti, "Land Use Changes and Sustainable Development in Mountain Areas: A Case Study in the Spanish Pyrenees,” Landscape Ecology, Vol. 11, No. 5, 1996, pp. 267-277. doi:10.1007/BF02059854

[65] M. Gay, "Regional Management and Soil Erosion Sensitivity,” Laboratory for Remote Sensing and Digital Mapping, Purpan Haigh School, Toulouse, 1996, pp. 1-8.

[66] W. Kelley, "Keep the Earth Alive: The Soil Erosion, Its Causes and Remedies,” FAO Soils Bulletin, Vol. 50, 1983, $62 \mathrm{p}$.

[67] M. C. Girard and C. Girard, "Processing of Remote Sensing Data,” DUNOD, Paris, 1999, 529 p. 